\title{
降雪片性状分析装置の開発研究
}

1。はじめに

秋田県地方の雪害には季節風型が卓越して発生す る場合と，海岸擾乱型による場合の二つのタイプが ある。これらは，いずれも比較的湿度の高い収束雲 によってもたらされる湿雪である。いわゆる除排雪 しにくい雪質なのであるが，このような降積雪を観 測し雪害をむたらす降雪の強さを評価する方法は未 だ確立されていない。ところで，雪がいかに激しく 降るかの程度を数舅的に表わす測定は，降雪片の赤 外線による反射パルス数や透過率を利用して行われ

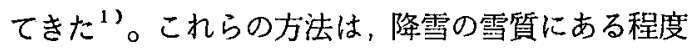
影響されるむののその空間的な密度に強く依存し， 降雪片の大きさや密度など雪害に関連する降雪強さ を測定していない場合が多い。本研究では降雪片の 大きさをリアルタイムで観測する装置を開発するこ とに着手したので，これまでの経過と問題点につい て，簡単に述べてみる。

\section{2. 測定方式について}

本研究の初期段階では降雪片の形状測定方式とし てスリット型透過センサーを検討した。この方式に よる予備的な実験結果によればスリット幅によって センサー出力に違いのあることが確認された。しか し，测定分解能がスリット幅によって直接的に制約
長谷川武司 ${ }^{*} \cdot$ 山崎宣 悦 $^{* *}$ 伊 藤 驍 ${ }^{* * *}$

されるため，より精度の高い測定を行うためには光 源とスリットの組み合わせを多数個用いなければな らない。寒冷地における長期間の測定にとって機器 の保守が容易であることは必須条件と考えられるこ とから，複数個のセンサーによるシステムを採用す ることは事実上困難である。

そこで，光源を 1 個に抑え，面積の大きい受光素 子と対向させ，降雪片による受光量の減衰を測定す ることによって降雪片の赛質形状を測定する方式を 検討することにした。これはシルェット剆定方式と 呼ばれるもので，図ー1にそのブロックダイアグラ ムを示す。この方式では 3 個の受光素子を左右一列 に配列し，それぞれの出力を演算増幅器によって変 換することで䛊りのないデータを得るようにしてあ る。すなわち，

1）無降雪時のセンサーの出力電圧を $V_{0}$ とおけば

LE D

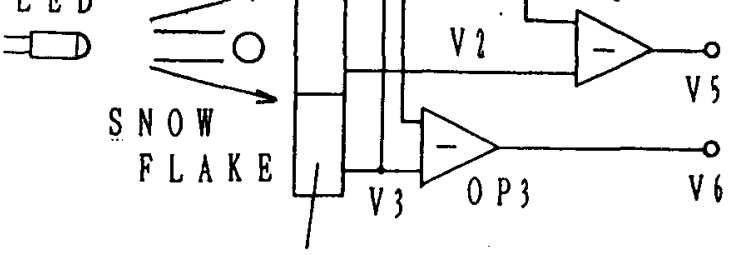

DETECTORS

図一1 シルエット測定方式による降雪片性状分析 装置のブロックダイアグラム。

* 秋田工専・助教授・応用物理 - 理博

** 橡レイディック・取締役主幹研究員

*** 秋田工専・土木工学科教授・工搏

〔本稿受理：1985年5月8日，改訂原稿受理：1989年 5 月31日，討論期限：1990年 6月30日] 


$$
\mathrm{V}_{1}=\mathrm{V}_{2}=\mathrm{V}_{3}=\mathrm{V}_{0}
$$

の関係が成立している。

2) 降雪時において，第 1 及び第 3 の受光素子の出 力が等しく，汃第 2 の受光素子の出力が透過光の 減衰によって減少する時点をデータ取り込みのタイ ミングとすれば, 各OPアンプの出力は

$$
\begin{aligned}
& \mathrm{V}_{1}=\mathrm{V}_{3}=\mathrm{V}_{0} \\
& \mathrm{~V}_{2}=\mathrm{k} \cdot \mathrm{V}_{0}(0<\mathrm{k}<1)
\end{aligned}
$$

と変化する。ところでOP ${ }_{1}$ の出力 $\mathrm{V}_{4}$ は， $\mathrm{V}_{1}$ と $\mathrm{V}_{3}$ の平均を得る演算を行っているので $V_{0}$ に等しく， さらにOP 2 によって $\mathrm{V}_{4}-\mathrm{V}_{2}$ の演算が行われるた め最終的に

$$
V_{5}=(1-k) \cdot V_{0}
$$

が得られる。すなわち，降雪片による透過光の減衰 に比例した信号はV $\mathrm{V}_{5} に$ 現われることになる。なお， $\mathrm{OP}_{3}$ の出力 $\mathrm{V}_{6}$ はデータ取り込みのタイミングを
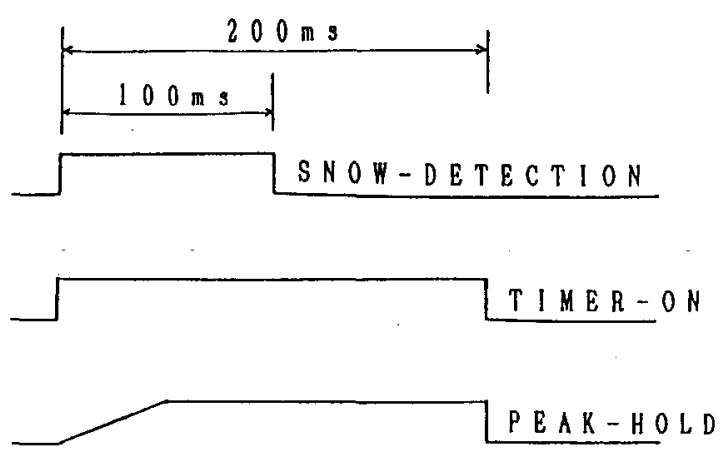

READ-START

AD CONVERSION

RESET

図一2 降雪片信号の取り込みに関する動作タイミ ングチャート。降雪検知信号によって，タイマー及 びピークホールド回路をスタートする。タイマー信 号は同じ降雪片を複数回カウントしないためのマス ク信号になっている。ピークホールドが十分安定し てから振幅値がAD変換される。
制限するマスク信号源となっている。以上緾めると， 降雪片検出以降における信号処理のタイムチャート は図ー2のようになり，1つの降雪信鱼が処理され る時間は200msである。

本機器では外乱光の影響を抑えるため，近赤外領 域のLEDをデューティ比 $50 \% ， 10 \mathrm{kHz}$ の矩形波に よって点灯する。一方，受光侧もLEDと一致する 分光感度特性の素子を用い，さらに受光面上にシャー プカットの赤外フィルターを貼り付けてある。受光 信号は, 電流一電厈の変換アンプを経た後, 中心周 波数 $10 \mathrm{kHz}$ のバンドパスフィルター，整流回路及び 時定数 0.2 秒の平滑回路を通り AD变換され，ディ ジタル記録計へ導かれる。

\section{3. 降雪片に対する機器の応答特性}

降雪片がセンサー部分の前を通過するとき，その 速度が有限であるため出力信号は立ち上がり，下が りの時間を有する。これに後段の增幅器やフィル ターなどの周波数特性が重瞕され最終的な出力信 号は変調を受けることになる。一方，降雪片とセン サーの距離が十分に近いことから：シルエットにお ける回折光の影響は無視しうると考えられる。従っ て測定精度は機器全体の応答特性に依存する。この ため降雪片を球状亡考え，その半径范び落下速度 $\mathrm{V}$ 与えて $\mathrm{AD}$ 変換部に入力される植前の信号が入 力信号に対しどの程度变調されているか数值的に検 討した。

光源が $10 \mathrm{kHz}$ の矩形波で点灯されていることを考 慮に入れ，降雪片による受光素子の出力波形を $\mathrm{f}(\mathrm{t})$ とすると，そのフーリエ変換 $F(\omega)$ は，

$F(\omega)=\int_{-\infty}^{\infty} f(t) \exp (-j \omega t) d t$

ここに, $\mathrm{j}=\sqrt{-1}$

で与えられる。一方, 受光側における電流一電圧変 換アンプ，バンドパスフィルター，整流回路及び平 滑回路に至る全システム関数をH $(\omega)$ とすると， 最終的な出力波形 $\mathrm{g}(\mathrm{t})$ は, $\mathrm{F}(\omega)$ とH $(\omega)$ の 積のフーリエ逆変換, 


$$
\begin{aligned}
g(t)= & (1 / 2 \pi) \int_{-\infty}^{\infty} F(\omega) H(\omega) \\
& x \exp (j \omega t) d \omega
\end{aligned}
$$

によって与えられる。関数 $\mathrm{f}(\mathrm{t})$ は降雪片の速度お よび半径によって決められるため， $16 \mathrm{~cm} / \mathrm{s} \sim 128$ $\mathrm{cm} / \mathrm{s}$ の 4 段階の速度， $0.5 \mathrm{~mm} \sim 4.5 \mathrm{~mm}$ の 9 段階の 半径を与元計算を行った。速度 $64 \mathrm{~cm} / \mathrm{s}$ に対する出力 例の一部を図ー3に示す。この図では振幅及び時間 について相対值を用い, シルエットの関数 $f(t)$ を 破線，出力g（t）を実線でそれぞれ表わしている。 図における半径 $3 \mathrm{~mm}$ 以下の， $f(t)$ に対するg $(\mathrm{t})$ の時間遅れは主として平滑回路の時定数によるすの と考えられるが，最大值を保持する機能を付加して あるので精度に及ぼす影響は殆ど無いであろう。と ころで,降雪片面積と出力振幅との関係は，図－4 に示すように，速度による影響の大きいことが明ら かになった。すなわち，16cm/sの速度では降雪片の 大きさ検出に頭打ちの傾向が存在すること， $32 \mathrm{~cm} / \mathrm{s}$

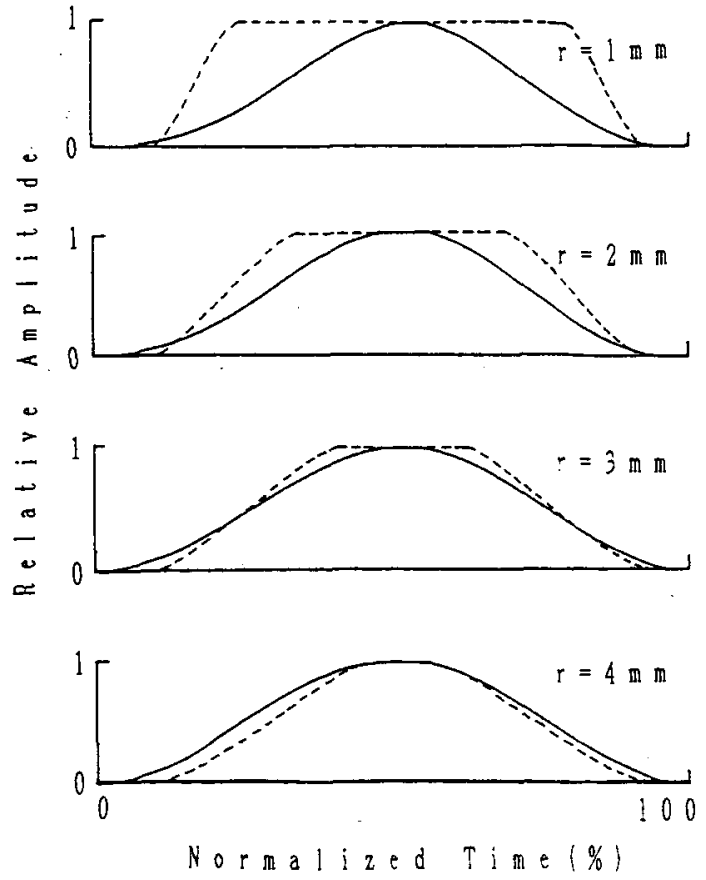

図ー3 降雪片のシルエットが受光面を通る時の関 数f $(t)$ 及び受光側システムによる変調を受けた出 力信号 $g(t)$ 。図で破線は $f(t)$ ，実線はg $(t)$ にそ れぞれ対応し，振幅值及ひ時間軸はそれぞれの最大 值及び 1 イベン当たりの時間で正規化されている。
以上では面積と出力の関係は直線的となるが，速度 の大きい雪片ほど出力振幅の下がることなどである。 これは立ち上がり時間が遅れる問題と同様に, 平滑 回路の時定数によるものであり，本機の使用条件を 限定している。

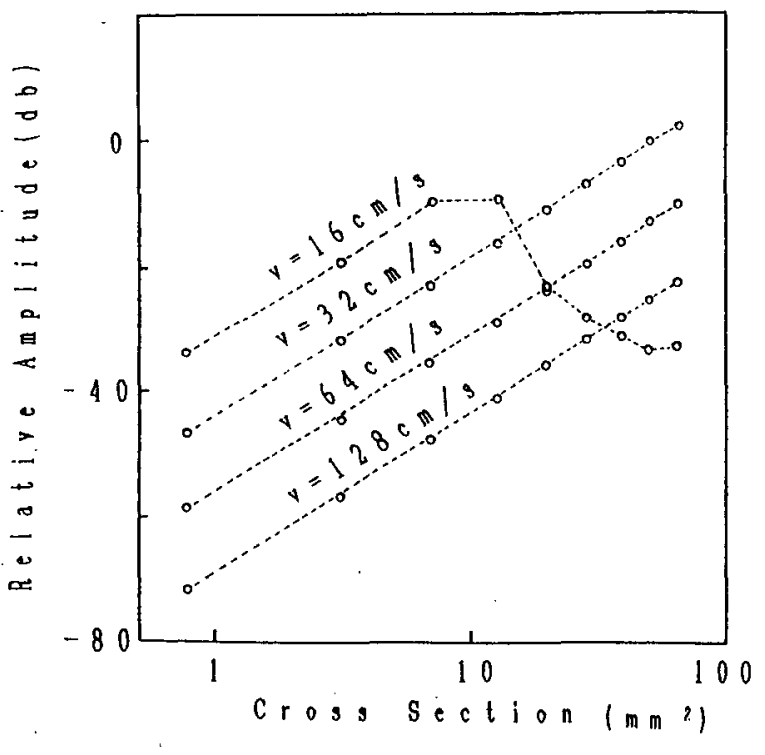

図-4 降雪片断面積（横軸）に対する出力信号の ピーク值 (綐軸) の関係。縦軸については，任意の 振偪值て正規化されている。

\section{4.おわりに}

本機器を用いた試験観測を1988年12月末から秋田 工専において行った（写真一 1 参照)。この観測は， 降雪片検出信号の立ち上がり時間調節により $60 \mathrm{~cm} / \mathrm{s}$ 程度の落下速度に対応している。この速度付近は， 暒川 $(1974)^{2)}$ による実測の結果を考慮すると，直 径 $1 \mathrm{~cm}$ 以内の降雪片について雪質の種類によらず検 出できる可能性がある。試験観測で得られたデータ は後に報告する予定であるが，機器開発段階で検討 された事項について纏めると，

（1）この方式は，受光素子が 3 個のため相互の感度 および応答性調整が行いやすい。 


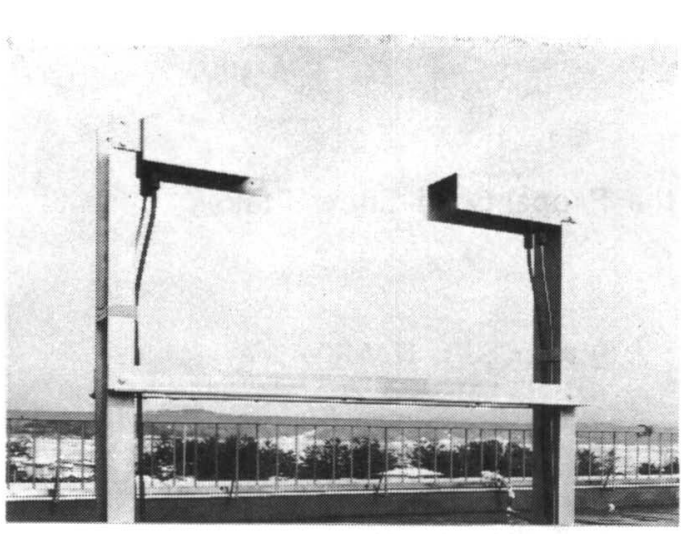

写真ー 1 秋田工専における試験観測。

発光側 (左手) と受光側を対向させフレームにセッ トしてある。

(2) 光源が 1 個であるため保守がしやすい。

(3) データ取り込みのタイミングに厳しい条件が付 けられているため光源と受光素子の間を正確に通過 した降雪片のみがカウントされる。

等の利点をもつ。

一方, 解決されるべき問題点として,

(4) 市販されている受光素子のサイズが $10 \mathrm{~mm} \times 20$ $\mathrm{mm}$ と小さいため降雪片径の最大值がこれによって決 ること。
（5）降雪片落下速度による信号出力への影響がきわ めて大きいこと。

などが挙げられる。これらは測定のダイナミックレ ンジと精度の向上を同時に要求するあのであり今後 の研究課題である。

\section{謝辞}

本研究費の主要な部分は, 文部省科学研究費補助 金・試験研究(1)，降積雪の性状分析機器開発に関す 万研究（課題番号62890009, 代表者 : 伊藤 驍）に よったことを付記する。

\section{参考文献}

1) 伊藤 驍 : 降積雪の時系列変動とその地域特性 に関する統計学的研究，財日本積雪連合資料， No.145, pp1 254, 1989.

2 ) 梶川正弘 : 雪片の落下速度の測定, 秋田工業高 専研究紀要, 第 9 号, pp83 87, 1974. 


\title{
SYNOPSIS
}

\section{Development of Instrumentation for the Property of Snow Flakes}

\author{
by TAKESHI HASEGAWA
}

\author{
Akita National College of Technology, \\ NOBUYOSHI YAMAZAKI \\ Radic Co. Ltd., \\ and \\ TAKESHI ITO \\ Akita National College of Technology.
}

A new detecting system for size of falling snow flakes is studied by optical sensing method. This system continuously covers $1 \mathrm{~mm}$ through $5 \mathrm{~mm}$ in radius. Falling velocity of snow flakes affects the system sensitivity, we tune it to about $60 \mathrm{~cm} / \mathrm{s}$ in velocity. Test observation, performed for $1988^{\prime} \mathrm{s}$ winter, shows that the new system works well and may be useful to detect the intensity of snow fall. 